\title{
PODEŽELJE NA PRELOMU TISOČLETJA: IZZIVI IN PROBLEMI
}

Podeželje kot polifunkcijski prostor v zadnjih desetletjih doživlja zelo močno preobrazbo: ponekod se z veliko intenzivnostjo razvija $\mathrm{v}$ gospodarskem, demografskem in prostorskem smislu, spet drugod so čedalje bolj očitne posledice zmanjšanja njegove gospodarske moči, desetletnega odseljevanja prebivalstva in zaraščanja kulturne pokrajine. Kako torej na eni strani ublažiti učinke modernizacije, suburbanizacije in intenzifikacije, po drugi pa »ohraniti« elemente nekoč (v prostorskem smislu) prevladujoče podeželske pokrajine? Kako usmerjati bodoči razvoj podeželja: ali ga prepustiti (trenutnim) razvojnim politikam ali pa poiskati specifične instrumente, ki naj bi pomagali modernizirati, a vendar vsaj v »določeni« obliki ohraniti specifične podeželske strukture? To so bila glavna izhodišča mednarodne znanstvene geografske konference o problematiki razvoja podeželja, ki je septembra 2001 potekala v organizaciji Oddelka za geografijo Filozofske fakultete Univerze v Ljubljani. Dvajset udeležencev iz Združenega kraljestva, Irske, Belgije, Nemčije, Avstrije, Estonije, Hrvaške in Slovenije je na tridnevnem srečanju razpravljalo o specifičnih razvojnih izzivih in problemih podeželja.

Konferenca je bila z organizacijskega in vsebinskega vidika precej dinamična, ker:

- $\quad$ so bili predstavljeni izsledki znanstvenih raziskav na področju podeželja s teoretičnega, aplikativnega in regionalnogeografskega vidika;

- je bila pripravljena tematska razstava s prikazom bogate dediščine raziskovanja podeželja v Sloveniji;

- je aktivno vključevala tudi študente 4. letnika, ki so zadnje študijsko leto pri vajah iz Geografije podeželja pripravili v sodelovanju z različnimi slovenskimi občinami (npr. Žužemberk, Loški Potok) ali institucijami (npr. v Brkinih) raziskovalne projekte;

- $\quad$ so udeleženci tridnevne konference dva dneva preživeli tudi na terenu (v Suhi krajini in Loškem Potoku);

- So občine aktivno sodelovale pri pripravi raziskovalnih projektov, organizaciji in izvedbi srečanja.

Problematika podeželja je bila celovito obravnavana. Bistvenega pomena so bile aktivne diskusije in izmenjave izkušenj pri reševanju podobnih problemov podeželja. Predstavljena je bila tipologija podeželja v Sloveniji, izpostavljeni so bili razvojni procesi in problemi agrarne strukture slovenskega podeželja (v primerjavi z državami Evropske zveze), problematika podeželja v Estoniji, Vzhodni Nemčiji, na Otoku Princa Edvarda v Kanadi, razvoj podeželja v zaledju Ljubljane, razvojne faze podeželja v valonski regiji v Belgiji. Nekateri prispevki pa so bili izrazito problemsko naravnani: razvoj dopolnilnih dejavnosti na kmetijah v Sloveniji, demografska problematika Idrijskega hribovja, razvoj turizma na kmetiji na Hrvaškem, oblike čezmejnega sodelovanja med Slovenijo in Avstrijo ter njihove posledice na podeželju. Izpostavljeno je bilo, kako je mogoče aktivirati endogene razvojne potenciale podeželja z okrepitvijo regionalnih gospodarskih krogov (na primeru Zgornje Pfalške na Bavarskem).

Referati so objavljeni v oddelčni publikaciji Dela.

Irma Potočnik Slavič 